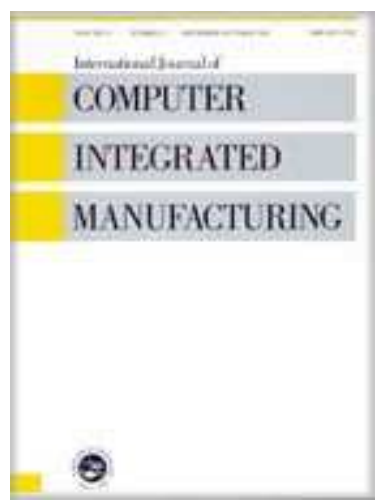

\title{
(Costing) Product-Service System Affordability in Defence and Aerospace Industries: State-of-the-art and Current Industrial Practice
}

\begin{tabular}{|c|c|}
\hline Journal: & International Journal of Computer Integrated Manufacturing \\
\hline Manuscript ID: & TCIM-2011-IJCIM-0022 \\
\hline Manuscript Type: & Special Issue Paper \\
\hline $\begin{array}{r}\text { Date Submitted by the } \\
\text { Author: }\end{array}$ & 21-Jan-2011 \\
\hline Complete List of Authors: & $\begin{array}{l}\text { Bankole, Oyetola; Cranfield University, Manufacturing } \\
\text { Roy, Rajkumar; Cranfield University,, Manufacturing } \\
\text { Shehab, Essam; Cranfield University,, Manufacturing } \\
\text { Cheruvu, Kalyan; Cranfield University,, Manufacturing } \\
\text { Johns, Terry; Ministry of Defence, DE\&S, Cost Assurance Team }\end{array}$ \\
\hline Keywords: & COSTING, COST IMPROVEMENT, LIFE CYCLE COSTING \\
\hline Keywords (user): & Product-Service System, Affordability prediction \\
\hline
\end{tabular}

\section{SCHOLARONE Manuscripts}


Product-Service System Affordability in Defence and Aerospace Industries: Stateof-the-art and Current Industrial Practice

Figures

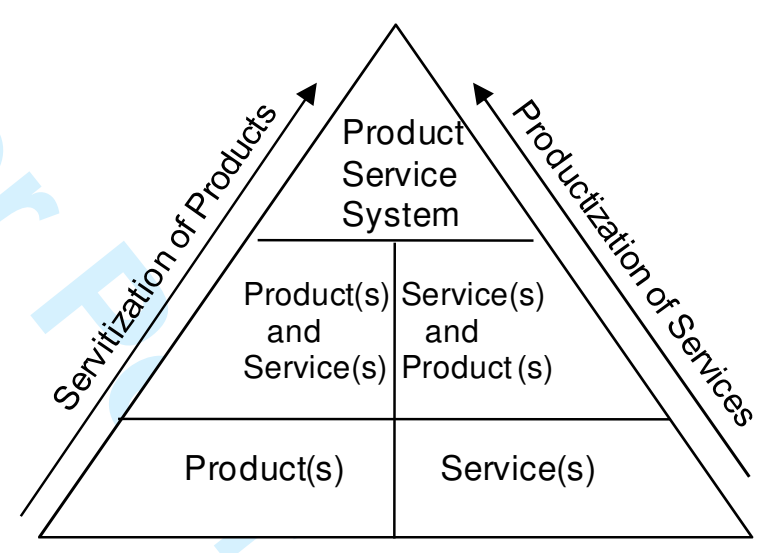

Figure 1: Evolution of PSS concept (Baines et al., 2007) 


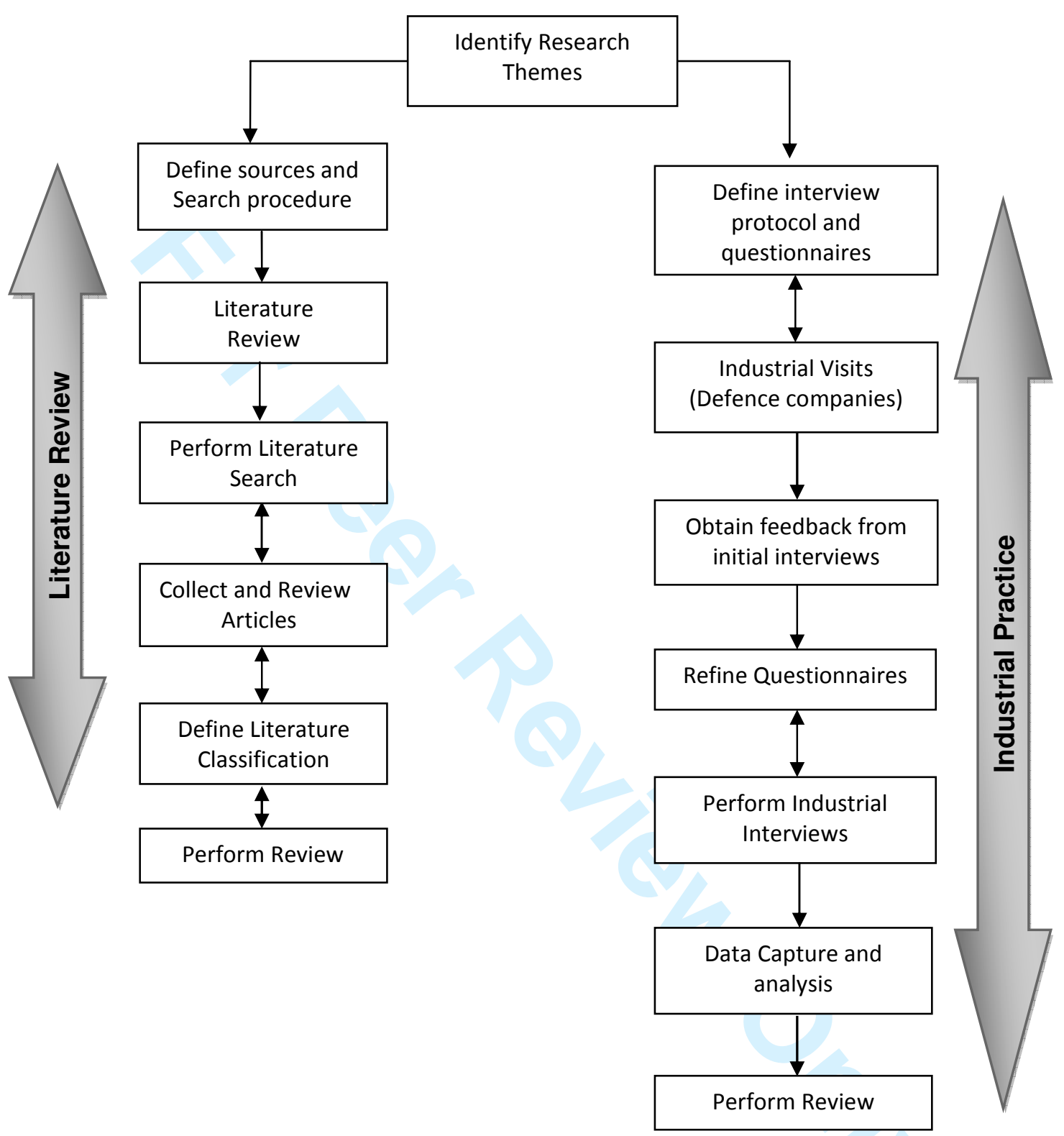

Figure 2: Research Methodology of State-of-the-Art Review and Industrial Interaction 


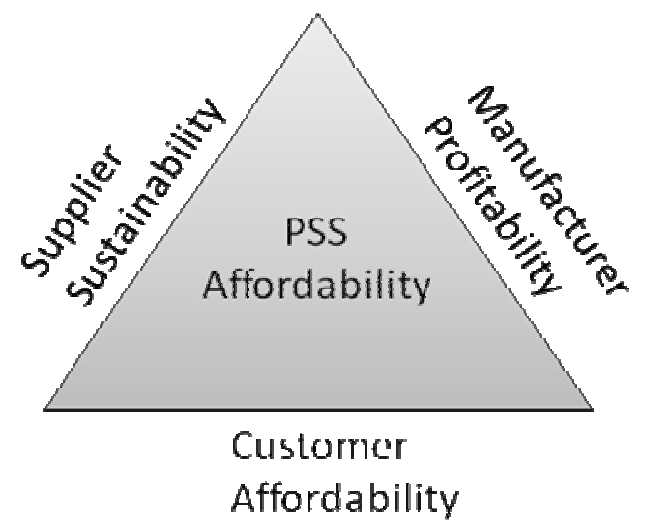

Figure 3: Affordability Engineering Framework

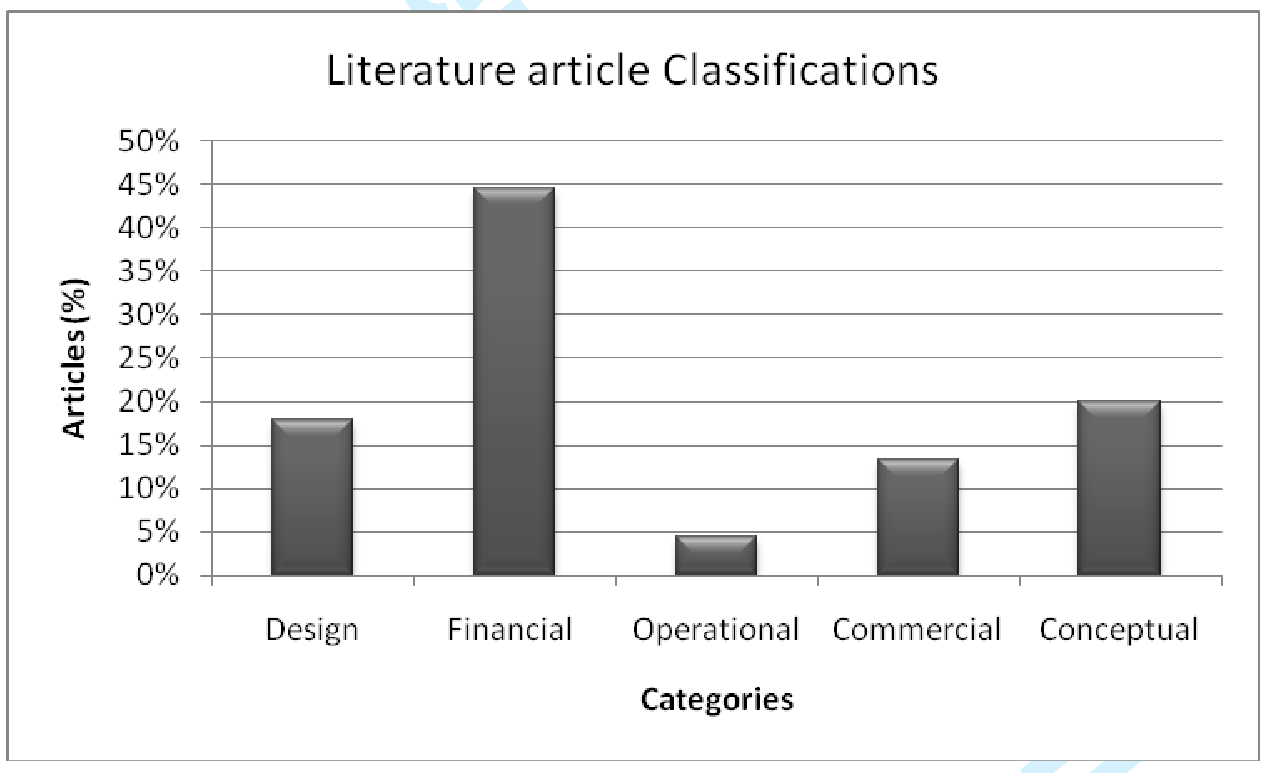

Figure 4: Classification of literature based on author's viewpoints 


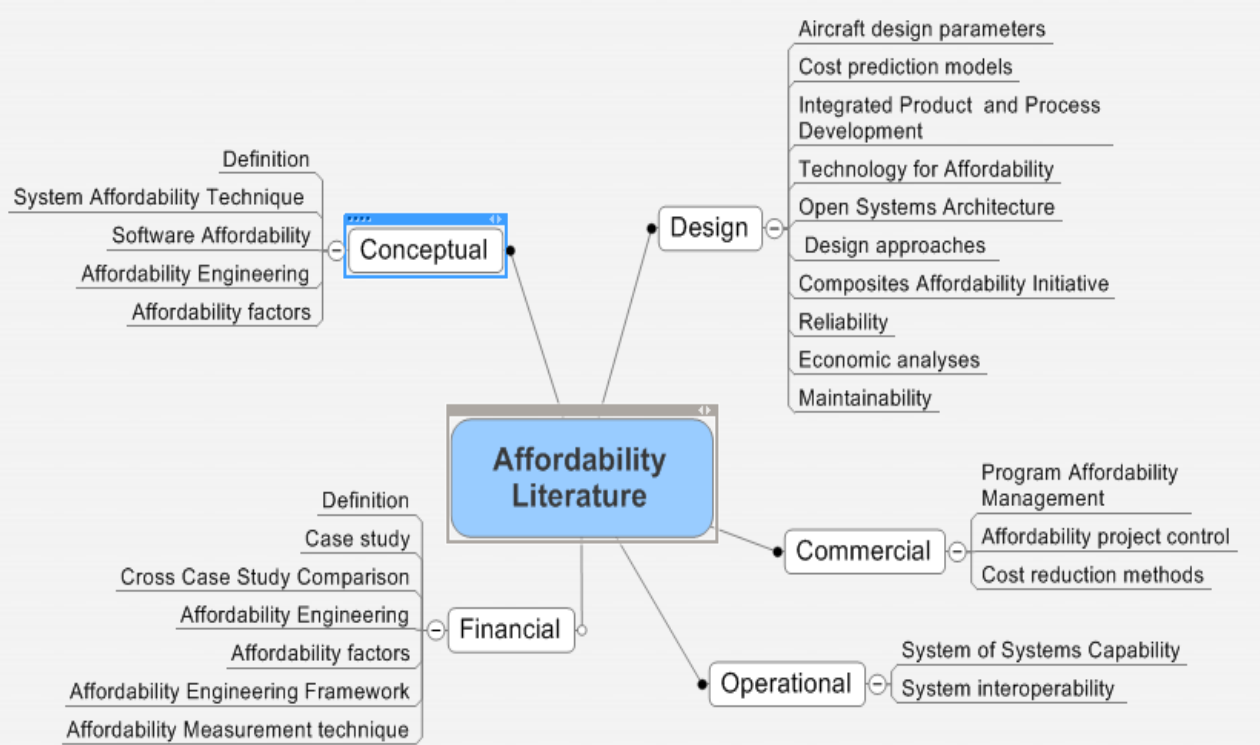

Figure 5: Main focus of the articles reviewed under the each classification.

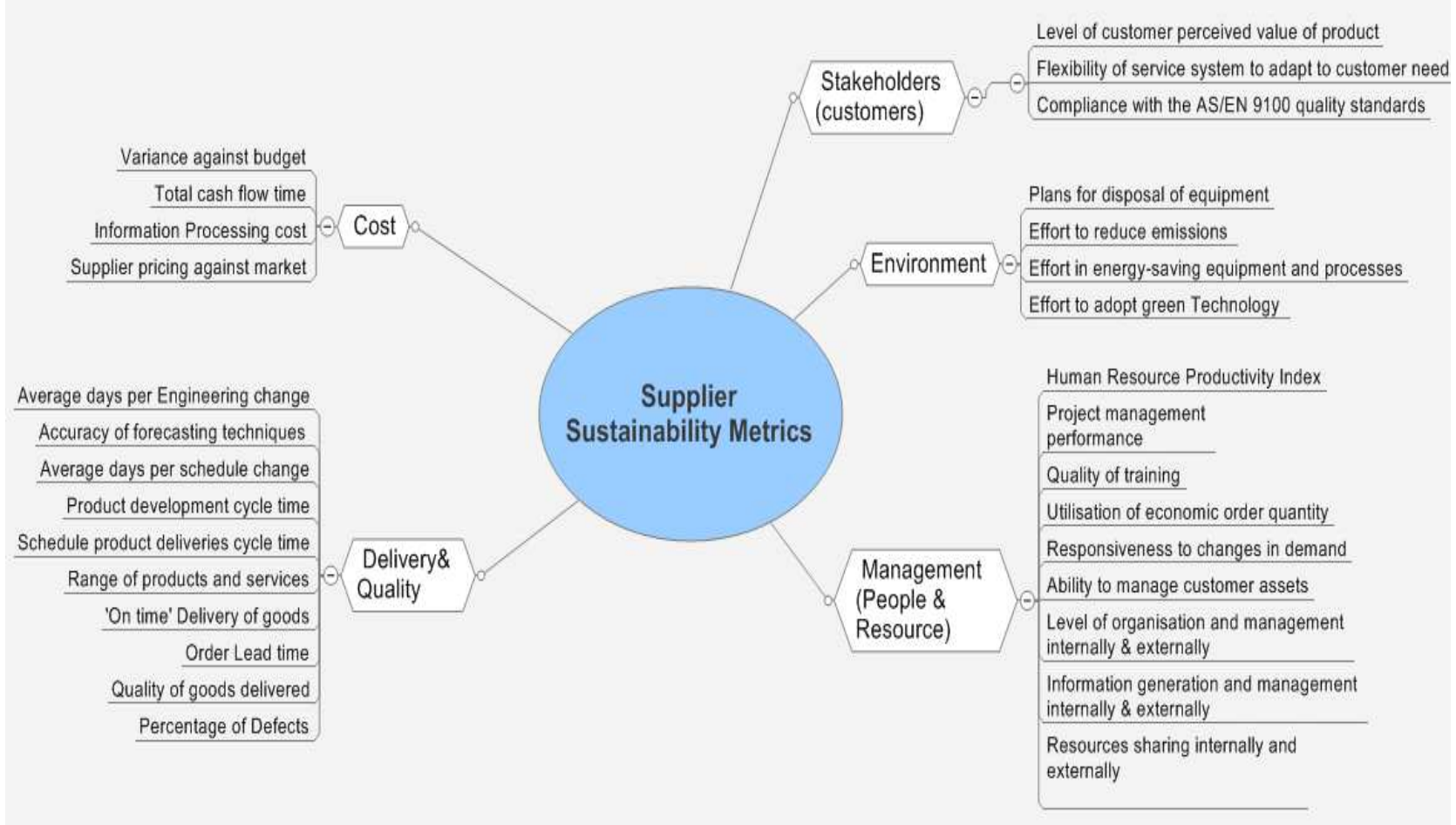

Figure 6: Supplier measurement metrics based on five dimension of sustainability

(adopted from Gunasekaran et al., 2004) 


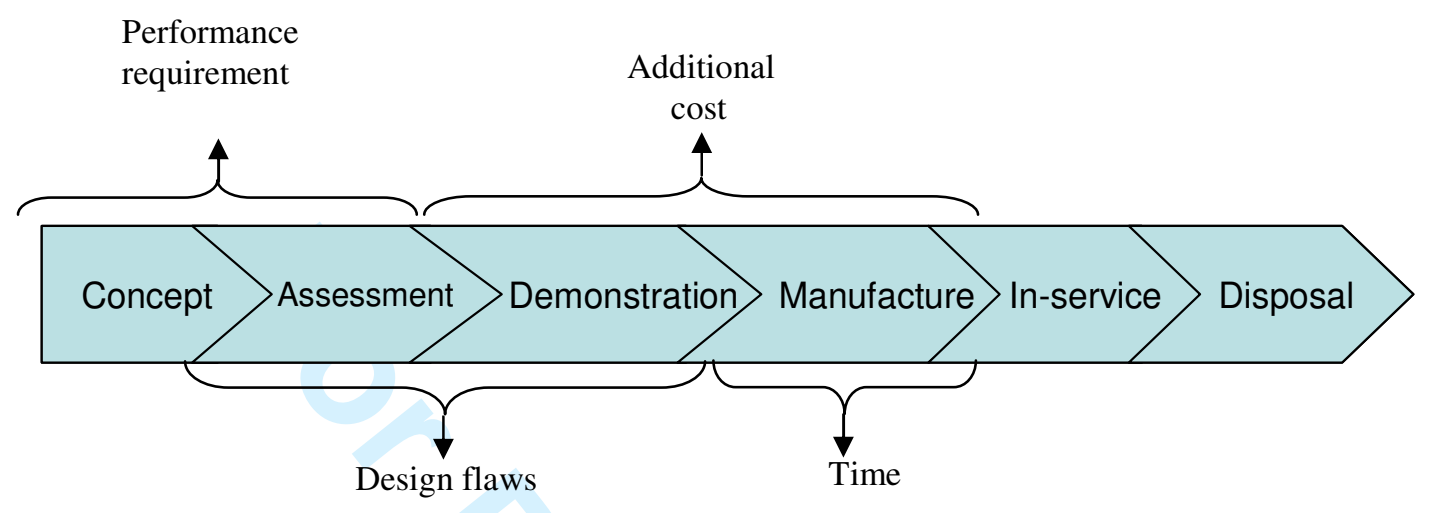

Figure 7: Causes of unaffordability across the CADMID Cycle 


\section{Product-Service System Affordability in Defence and Aerospace Industries: State- of-the-art and Current Industrial Practice}

Tables

Table 1: Literature Review Article Classification and references

\begin{tabular}{ll}
\hline Classification & References \\
\hline Design & Kong D., De Kock F. (1997), Russell J.D. (2007), Chytka T.M., \\
& Brown R.W., Shih A.T., Reeves, J.D., Dempsey J.A. (2006), Ray A. \\
& (2006), Rains $\quad$ D. A. (1996), Daugherty G.(1989), Schrage D.P. (1999), \\
& Lee A.J. et al (2006). \\
Financial & Jaffe, M. O. (1983), Rubbin S. (1994), Guimaraes L., Caraleanu C., Sy \\
& B., N'Dongo A., Sankare O. (2003), Hancock K.E. (1993), Centre for \\
& Transit Oriented Development and Centre for Neighbourhood \\
& Technology (2006), Kroshl W. M., Pandolfini P.P (2000), Milne C. (2000), \\
& Lerman D.L., Reeder W.J. (1987), Redman Q., Stratton G. (2001), Roy \\
& R., Adesola B., Nogal Miguel S. (2006), Ray. A., Roy R. (2007), \\
& Fankhauser S., Sladjana T. (2006), Nogal S.(2006), Tsolacos S., \\
& McGough T., Thompson B. (2005), Al-Churaiz Y., Enshassi A. (2005), \\
& Mueller M.L., Schement J.R. (1996), Finlay S.M.(2008), (Semple J, \\
& 2007). \\
& Minkiewicz A.F. (2006), Roark C., Kiczuk B. (1997). \\
& Reagan L. (2005), Young R., Reagan L. (2004), Reagan L. (2004), \\
& Schmidt J., Hitt E. (1999), Soraya M., Lambert H., Cooper D. (2000), \\
& DeMarco A. (2005) \\
& Bradbery R. (2005), Ray A., Baguley P., Roy R. (2006), Baines T. et al \\
& (2007), Marasco A. (2008), Ngai E.W., Moon K.K., Riggins F., Yi C.Y. \\
& (2008), Smyth P. (2005), Mutchler J., Krivo L. (1989), Berver B., \\
& Collofello J.S. (2002), Bankole O.O., Roy R., Shehab E., Wardle P. \\
& (2009). \\
Coperational & \\
Commercial &
\end{tabular}

Table 2: Affordability Qualitative factors within defence and aerospace industries 


\begin{tabular}{|c|c|}
\hline $\begin{array}{l}\text { Affordability } \\
\text { Factors (AF) }\end{array}$ & Description \\
\hline $\begin{array}{l}\text { World Economic } \\
\text { Climate (WEC) }\end{array}$ & $\begin{array}{l}\text { The economic climate is affected by the inflation, interest rate and share prices. } \\
\text { Exchange rate fluctuation between two currencies determines how much one currency } \\
\text { is worth in terms of the other. This could have a negative or positive effect on } \\
\text { customer affordability. }\end{array}$ \\
\hline $\operatorname{Risk}(\mathrm{R})$ & $\begin{array}{l}\text { This is defined as the combination of the probability of any event occurring and its } \\
\text { consequences (positive or negative) on the PSS offering. This should be assessed and } \\
\text { adequate provision should be made while contracting including ways of turning it into } \\
\text { an opportunity. }\end{array}$ \\
\hline $\begin{array}{l}\text { Environment } \\
\text { (E) }\end{array}$ & $\begin{array}{l}\text { This refers to the responsibility of firm towards the environment to ensure that their } \\
\text { operations and activities are environmentally friendly to ensure sustainability. }\end{array}$ \\
\hline $\begin{array}{l}\text { Value For Money } \\
\text { (VFM) }\end{array}$ & $\begin{array}{l}\text { The customer assesses tender responses for a PSS provision from the solution provider } \\
\text { against VFM. This could be done by employing three techniques namely: economy, } \\
\text { efficiency, effectiveness. }\end{array}$ \\
\hline Legislation (L) & $\begin{array}{l}\text { Changes in UK, EU and International law, regulations, and protocols concerning } \\
\text { environmental, safety, social issues can affect affordability. These impacts both the } \\
\text { WLC at the outset of the project and the affordability of extant projects. }\end{array}$ \\
\hline Quality (Q) & $\begin{array}{l}\text { Customer focuses on a specific project and the financial commitment involved in that } \\
\text { project to ascertain that the solution is delivered at high quality. Therefore, customer } \\
\text { affordability is influenced by perception and interpretation of quality. }\end{array}$ \\
\hline Supply Chain (SC) & $\begin{array}{l}\text { Lower tier suppliers are crucial to the delivery of both products and services for the } \\
\text { duration of the availability or capability contract life. The challenge is to ensure } \\
\text { continuity in the supply chain over the contract life. }\end{array}$ \\
\hline Requirement (RQ) & $\begin{array}{l}\text { Customer requirement forms the basis of the contract and a change of requirement } \\
\text { could increase the whole life cost of the project where extra effort is required in } \\
\text { redesigning the system especially with be-spoke systems and services. }\end{array}$ \\
\hline $\begin{array}{l}\text { Global Competition } \\
\text { (GC) }\end{array}$ & $\begin{array}{l}\text { The rules of competition drive the cost down. If competitors are offering lower prices, } \\
\text { the supplier could be forced to reduce the cost of the service. } \\
\text { Suppliers/contractors from other countries could provide attractive offers in order to } \\
\text { expand their customer base. }\end{array}$ \\
\hline $\begin{array}{l}\text { Performance- } \\
\text { Related measure } \\
\text { (PRM) }\end{array}$ & $\begin{array}{l}\text { In some contracts, full payment is made upon contract delivery; hence the level of } \\
\text { customer satisfaction with the delivery and performance of capability could impact the } \\
\text { customer's willingness to pay based on system or equipment performance. This is } \\
\text { linked directly to performance management. }\end{array}$ \\
\hline $\begin{array}{l}\text { Political Climate } \\
\text { (PC) }\end{array}$ & $\begin{array}{l}\text { The defence industry's operations are typically affected by the nation's political } \\
\text { climate. Perceived threats from other nations, could affect the government's } \\
\text { willingness to invest in defence projects. }\end{array}$ \\
\hline Unknown (U) & This applies to any other factors which arise depending on the nature of the project. \\
\hline
\end{tabular}

Table 3: Profitability assessment 


\begin{tabular}{|l|r|}
\hline Item Description & Year 1 \\
\hline Labour & $\mathbf{x x}$ \\
\hline Overheads & $\mathrm{xx}$ \\
\hline Materials & $\mathrm{xx}$ \\
\hline Supply chain & $\mathrm{xx}$ \\
\hline Total Basic Cost & $\mathrm{xx}$ \\
\hline Contingency & $\mathrm{xx}$ \\
\hline Escalation & $\mathrm{xx}$ \\
\hline Profit at \% on Cost & $\mathrm{x}$ \\
\hline Sub Total & $\mathrm{xxx}$ \\
\hline Basic Selling Price & $\mathrm{xxx}$ \\
\hline Warranty & $\mathrm{x}$ \\
\hline Penalty & $\mathrm{x}$ \\
\hline Total Add-On Costs & $\mathrm{xx}$ \\
\hline Selling price + Total Add-on-Cost & $\mathrm{xxx}$ \\
\hline Offer Price & $\mathrm{xxx}$ \\
\hline
\end{tabular}

Table 4: Comparison of findings from academic research and industrial practice 


\begin{tabular}{|c|c|}
\hline \multicolumn{2}{|l|}{ Customer affordability } \\
\hline Academic research & Industry practice \\
\hline $\begin{array}{l}\text { In academia, the concept of affordability is } \\
\text { in its infancy even though the words } \\
\text { "afford", "affordable" or "affordability" are } \\
\text { commonly used. The standard definition } \\
\text { employed within this paper was formulated } \\
\text { by Ray et al., 2006. }\end{array}$ & $\begin{array}{l}\text { Within industry, customer affordability is } \\
\text { usually seen as a factor which affects the } \\
\text { delivery of defence solutions. For this } \\
\text { reasons, there is no formal definition of } \\
\text { customer affordability in industry. }\end{array}$ \\
\hline $\begin{array}{l}\text { In academia, some methods were } \\
\text { developed to assess customer affordability } \\
\text { including the Al. This assessment method } \\
\text { was refined in this paper to make it more } \\
\text { suitable for the aerospace and defence } \\
\text { industries. }\end{array}$ & $\begin{array}{l}\text { Within industry, not much work has been } \\
\text { done to develop methods of assessing } \\
\text { customer affordability for the aerospace and } \\
\text { defence industries; rather a comparison is } \\
\text { made between the WLCC and CATS. }\end{array}$ \\
\hline \multicolumn{2}{|l|}{ Manufacturer Profitability } \\
\hline Academic research & Industry practice \\
\hline $\begin{array}{l}\text { Profitability is usually not defined, rather it is } \\
\text { calculated and measured both within industry } \\
\text { and academia. }\end{array}$ & $\begin{array}{l}\text { Profitability is usually not defined, rather it is } \\
\text { calculated and measured both within industry } \\
\text { and academia. }\end{array}$ \\
\hline $\begin{array}{l}\text { In academia, profitability assessment is well } \\
\text { established, but the focus is usually on } \\
\text { profitability at the end of the financial year. }\end{array}$ & $\begin{array}{l}\text { Within industry, there are methods } \\
\text { employed is assessing manufacturer } \\
\text { profitability both at the bidding stage and the } \\
\text { end of the financial year. The focus on } \\
\text { profitability in defence contracts at the } \\
\text { bidding stage is to arrive at a competitive } \\
\text { selling price. There are established } \\
\text { techniques for performing this assessment } \\
\text { which vary from one manufacturer to } \\
\text { another. }\end{array}$ \\
\hline \multicolumn{2}{|l|}{ Supplier affordability } \\
\hline Academic research & Industry practice \\
\hline $\begin{array}{l}\text { In academia, there is no definition for } \\
\text { supplier sustainability, however a definition } \\
\text { have been developed by the authors of this } \\
\text { paper. }\end{array}$ & $\begin{array}{l}\text { Within industry, there is also no definition for } \\
\text { supplier sustainability as the concept is } \\
\text { emerging from academia. }\end{array}$ \\
\hline $\begin{array}{l}\text { In academia, there are methods employed } \\
\text { is assessing supplier performance and } \\
\text { continuous improvement, but they are not } \\
\text { focussed on financial sustainability. Some } \\
\text { measures of supplier sustainability have } \\
\text { been suggested by the authors of this paper } \\
\text { which were derived from existing } \\
\text { performance measures. }\end{array}$ & $\begin{array}{l}\text { Within industry, not much work has been } \\
\text { done to develop methods of assessing } \\
\text { supplier sustainability. Existing measures } \\
\text { are focussed on measuring supplier } \\
\text { performance. }\end{array}$ \\
\hline
\end{tabular}




\section{Glossary of Terms}

\begin{tabular}{|l|l|}
\hline Acronym & Meaning \\
\hline PSS & Product Service Systems \\
\hline CADMID & $\begin{array}{l}\text { The Concept, Assessment, Demonstration, Manufacture, In-service, Disposal cycle } \\
\text { has been used by the United Kingdom Ministry of Defence (MOD) since 1999, } \\
\text { when it was devised as part of the Smart Procurement initiative, since replaced by } \\
\text { Smart Acquisition, to deliver equipment capability within agreed performance, cost } \\
\text { and time parameters. }\end{array}$ \\
\hline WLCC & $\begin{array}{l}\text { Whole Life Cycle Cost refers to the holistic view of cost end-to-end across the } \\
\text { CADMID cycle. }\end{array}$ \\
\hline CATS & Customer Available to Spend (a major factor in calculating the affordability index) \\
\hline PBL & Performance-Based Logistics \\
\hline DoD & US Department of Defence \\
\hline MoD & UK Ministry of Defence \\
\hline AI & Affordability Index \\
\hline NATO & North Atlantic Treaty Organisation \\
\hline VFM & Value For Money \\
\hline NPV & Net Present Value \\
\hline NoE in AE & Network of Excellence in Affordability Engineering \\
\hline LCCA & Life Cycle Cost Analysis \\
\hline TLC & Through Life Costing \\
\hline CPA & Customer Profitability Analysis \\
\hline SC21 & $21^{\text {st }}$ Century Supply Chain Initiative \\
\hline
\end{tabular}




\section{Product-Service System Affordability in Defence and Aerospace Industries: State-of-the-art and Current Industrial Practice}

Ms Oyetola Bankole ${ }^{1}$, Prof Rajkumar Roy ${ }^{1}$, Dr Essam Shehab ${ }^{1}$, Dr Kalyan Cheruvu ${ }^{1}$ and Mr Terry Johns ${ }^{2}$

${ }^{1}$ Manufacturing Department, Cranfield University, Cranfield, Bedfordshire, MK43 OAL, United Kingdom

${ }^{2}$ DE\&S Ministry of Defence, Abbeywood, Bristol, BS34 8JH, United Kingdom

\section{$\underline{\text { Abstract }}$}

This paper reviews through life costing practice with affordability considerations. This provides a holistic view of through life costing by assessing the customer's financial ability to procure and support defence contracts, particularly at the bidding stage. The paper reviews literature on affordability from three perspectives of the customer (affordability), manufacturer (profitability) and supplier (sustainability) then reports industrial practice within the aerospace and defence industries. The paper is aimed at securing definitions, methods of assessment and management of affordability. This is achieved through the review of literature materials and current industrial practice within the defence and aerospace industries. The main contribution of the paper is that it provides the state- of -the-art review of affordability from the three perspectives and together with definition and assessment methods for affordability. The findings helped to identify qualitative and quantitative factors affecting affordability and assessment techniques from the three affordability perspectives. Also a gap analysis of literature and current industrial practice in terms of definitions and assessment methods was performed based on research findings. The paper provides direction for future research in affordability based on the three perspectives of 
affordability. The limitation of the review is its focus on defence and aerospace industries without including other industries, however this was done in order to maintain the focus of the paper.

Keywords: Product-Service System, Affordability prediction, Customer affordability, manufacturer profitability, supplier sustainability

\section{INTRODUCTION}

Product-Service System (PSS) is an integrated product and service offering that delivers value in use (Baines et al., 2007). Geodkoop et al., (1999) provide a comprehensive definition of a PSS being 'a system of products, services, networks of "players" and supporting infrastructure that continuously strives to be competitive, satisfy customer needs and have a lower environmental impact than traditional business models'. The emphasis on the integration of the product and service of the PSS concept is illustrated in Figure (1). In the PSS model, the customer pays for the use of an asset, rather than its purchase, thereby realising the advantage of restructuring risks, responsibilities, and costs normally associated with ownership in traditional business contracts (Baines et al 2007). In this business model, the solution provider offers the availability of products or equipment with supporting services while the customer pays for the integrated PSS offering. Generally, a PSS has the following features:

- a physical product core (e.g. aero engine) enhanced and customised by a non-physical service shell (e.g. maintenance, training, operation, disposal)

- relatively higher monetary value and importance of the physical PSS core compared to traditional business model 
- a 'business to business' relationship between PSS solution providers and their customers (Aurich et al., 2006).

Insert Figure (1) here

While eight types of PSS have been identified across different industries, Tukker (2004) broadly categorised them under three headings namely; product oriented, use-oriented and result-oriented. The product oriented PSS is focussed on the sale of products with additional services attached to it. The use- oriented PSS is designed to ensure that ownership of products remains with the service provider but it is made available to the users while the result-oriented is focussed on achieving the result which is desired by the customer and solution provider, rather than selling a product. One example of a PSS in the aerospace sector is the Rolls Royce 'power-by-the-hour' service for its gas turbine engines offered to airline customers as part of the Total-Care package. Here the customers pay for the use of the engines (use oriented) while the manufacturer retains the ownership and bears risks associated with the operation and maintenance of the equipment. This type of use-oriented PSS category is common in the defence and aerospace industries as seen in availability contracts (Erkoyuncu, et al., 2009). Terms like Industrial PSS and Performance-Based Logistics are also used to refer to PSS (Roy and Cheruvu, 2009) since all these are PerformanceBased contracts. Examples of PSS within the defence and aerospace industries are defence projects within availability contracts such as Harrier Platform Availability Contract and the UK's Eurofighter Typhoon fleet which provides availability of platform and fleet of aircrafts by the solution providers. This paper focuses on the use-oriented PSS category in the form of availability contracts since capability contracting (result-oriented) is the destination for the defence sector. The lifecycle of a typical PSS project within the defence industry is represented in the Concept, Assessment, Demonstration, Manufacture, In-service and Support phases (CADMID). Similar to 
the Rolls Royce Total-Care package, the manufacturer takes responsibility for repairs, maintenance and other services required to deliver the expected functionality and satisfy user requirement.

The nature of these contracts which comprise of high-value products and services which last for a long duration between 5 and 40 years requires a comprehensive method of through life cost estimation which would take account of various activities involved at different phases of the project or programme life cycle agreed in the contract (Meier et al., 2010). Roy and Cheruvu (2009) designed a framework for a competitive PSS which explained that risks and uncertainties affect the success of a PSS, hence they must be accounted for when estimating the cost of PSS. In addition to through life cost estimation, it is important to assess the customer's ability to support the PSS through life, because the success of a PSS is not only based on accurate cost estimation, but the customer's financial capability to support the contract (Bankole et al., 2010). This assessment of the customer's ability to fund the PSS is described as customer affordability assessment. The aim of this paper is to describe the state-of-the-art research in affordability from three different perspectives such as customer affordability, manufacturer profitability and supplier sustainability and underline areas of improvement and as well as stimulate future research. The term 'affordability' refers to the three affordability perspectives (customer affordability, manufacturer profitability and supplier sustainability) while ‘customer affordability' refers to one of the three perspectives. Initially the main focus of affordability was on customer affordability, as the major perspective but during interaction with industrial partners, the other two perspectives were discovered as being important also. A review of customer affordability across different sectors revealed that the concept is a familiar one in industries such as construction and utility, but it is a new research area in the aerospace and defence industries. Within this paper, only the 
literature review from the aerospace and defence industries are presented in order to maintain the focus of the paper within these industries. This is shown by the limited number of literature available on the topic, suggesting that little effort has been employed in overall state-of-the-art on customer affordability. Since the main novelty lies within the customer affordability research, more findings on the subject were reported in this paper in comparison with the other two perspectives, nevertheless a thorough review of the three perspectives was done. This study reviews the concept of overall affordability both from literature and industrial practice in the aerospace and defence industries.

\section{Methodology}

\subsection{Research method}

The content analysis research and delphi methods were employed in this study as they were the most suitable to achieve the aim of the paper, to understand the state of research in affordability. Content analysis involves two steps; (i) define sources and procedures for the search of articles to be analysed and (ii) define categories which are employed to the classification of the collected articles (Marasco 2008). Both published and unpublished literature was involved in the review. While this paper includes the PSS theme, the main area of focus is affordability, hence most of the literature reviewed centred on affordability from the three perspectives. The research methodology adopted in this review is captured in a flow chart and presented in Figure (2) to reflect both literature review and industrial practice. The process began with the identification of research themes around affordability. Then extensive literature search on academic content between 1983 and 2009 was carried out and the results were analysed according to subject areas. Insert Figure (2) here 
The literature search was conducted using databases such as Compendex, Inspec, and Emerald; using key words such as “Affordability”, “Affordability in Product Service System”, 'Supplier Performance', 'Supplier Management', 'Performance measurement' and 'Profitability' as the keywords. The search results were narrowed down to focus on the relevant materials. These materials were collected and reviewed during which the method of classification was defined. After initial literature review, the Delphi research method was applied in order to capture the opinions of industry experts due to the fact that the study of affordability is in its infancy within academia. An interview protocol was developed which involved semi-structured interviews with industrial experts within the aerospace and defence sectors (two manufacturers and one customer firms). The research themes were refined as a result of findings from initial literature review and the initial industrial visits. Some of the questions employed in conducting the interviews are as follows:

- What is your understanding of affordability and what factors affect affordability?

- How would you assess the financial sustainability of suppliers in defence projects at the bidding stage

- How do you assess profitability at the bidding stage?

- What additional risks come in terms when contracting for availability contracts - the financial burden on the customer?

More than 30 hours of interviews were conducted and each interview session lasted 120 minutes in average. The profiles of the experts interviewed are described below.

- Project manager - Responsible to deliver contracts to customers on time, on schedule; within the project. Also to manage resources effectively and deliver on budget as well as overseeing the Engineering team. 
- Business Development Leader - Responsible for working to understand current and future training needs and to develop the company strategy and tactics for maximising the opportunity in the market place.

- Set Assurance Team Leader - Involved in examining Business Cases and estimations. A key member of the Integrated project team who is also involved in Through life analysis of Business cases.

- Engineering manager - Responsible for the day-to-day (technical) problem solving as well as the delivery of contracts to meet customer requirement within the budget.

Data was collected and analysed using the MindManager software which helped to produce Mind maps based on various themes identified. Initial interviews were conducted with functional experts and the employees whose profiles were presented above. The results of the interviews were presented back to the experts in form of reports to be validated. This provided the researcher with background understanding of PSS offerings within the defence industry. Another set of questionnaires were developed based on the result of the previous interview session to carry out further interviews. More data was obtained also from company documents to help the researchers gain a better understanding of PSS solutions within the defence and aerospace industries. Software such as Microsoft Visio (flowchart) was employed in visualising processes and identifying relationships within the concept of affordability.

\subsection{Validation}

The results of the initial interview sessions were validated by the researchers presenting the outcome and analysis of the interviews in the form of company reports which were delivered to the industrial experts together with recommendations for improvement. The experts reviewed the reports and provided corrections and clarification of issues where necessary. 
The next validation session was done at a meeting held with industrial experts both from the customer firm and the manufacturer firms. At other meetings with both firms, the researcher delivered power point presentations based on literature review and carried out semi-structured interviews. The meeting with the customer firm which lasted for 120 minutes focussed on understanding and capturing customer affordability. The questionnaires were focussed on clarifying the factors affecting affordability and factors leading to un-affordability. These results of this session helped to determine the process and factors involved in customer affordability assessment as well as the causes of un-affordability. With the manufacturer firm, the focus was to understand manufacturer profitability and supplier sustainability. One set of questionnaires was focussed on clarifying the elements considered in measuring manufacturer profitability and another focussed on capturing the process and measures of supplier sustainability. Both sessions were held separately. The manufacturer profitability validation session which lasted for 110 minutes, helped to identify the focus and elements considered in assessing manufacturer profitability at the bidding stage. The supplier sustainability validation session which lasted for 120 minutes, led to the discovery of the fact that the assessment of suppliers was based on their current performance after they had been contracted to be partners in delivering a defence project. Manufacturers were employing existing measures from the $21^{\text {st }}$ Century Supply Chain initiative and other measures derived internally to assess the performance of their suppliers, but there is insufficient effort in assessing long-term operational and financial sustainability. The outcomes of the industrial validation sessions are included in this study. 


\section{AFFORDABILITY PERSPECTIVES}

Marasco (2008) adopted two-dimensional classification based on research approaches and methodology adopted in performing an extensive literature review of third-party logistics across different industries. The dimensions employed were from theoretical to empirical and from prescriptive to descriptive since the research area under review was mature. The empirical studies involved surveys, case studies or interview while the theoretical studies were concerned with the development of models, concepts or conceptual frameworks. This form of classification method for extensive review could have formed the basis for classification within this paper if more research had been done in the area of customer affordability, but this is not the case as the research area is not mature. For this reason, the authors decided to classify the literature articles based on the authors' viewpoints expressed in the articles which could include the classification dimensions mentioned above. A general search using ‘affordability' yielded results across many industries including construction, but this paper focuses on the aerospace and defence industries. This explains why only materials within the aerospace and defence industries are being reviewed within this paper. Affordability is a new research concept within the aerospace industry and is in the process of establishing management and measurement techniques which are approved by both industry and academia. From both industrial practice and literature reviewed, affordability can be viewed from customer, manufacturer and supplier perspectives.

\subsection{Customer affordability}

Redman and Stratton (2001) defined customer affordability as the "characteristic of a product or service that makes it possible for the consumer to':

- Procure it when it is needed

- Use it to meet their performance requirements at a level of quality that is desired 
- Use it whenever it is needed over the expected life cycle of the product or service

- Procure it for a reasonable cost that falls within the customer's budget for product or service.

This definition implies that customer is concerned about the availability of the product or service, its functionality and cost effectiveness for an expected life cycle. Hence, customer affordability focuses on the customer's ability to pay for the product or service provided by the manufacturer usually, this is affected by the customer's perception of value and the worth of the product offering ( $\mathrm{Ng}$ et al., 2009).

\subsection{Manufacturer profitability}

Ray (2006) has defined manufacturer affordability (profitability) as 'the characteristic of the aircraft component and manufacturing systems and processes required to be procured when it is needed and supported so it remains available as needed and operated at the level of performance and quality desired within the budget allocated to systems that are being procured'. Redman and Stratton (2001) also defined manufacturer affordability as the "characteristic of a product or service that':

- Makes it available when the customer initially needs it

- Enables it to meet customers' performance requirements at a level of quality they demand

- Makes it available whenever customers need it during its expected life cycle

- Allows customers to fit into their budget for product or service.

While this definition reflects that of customer affordability, the difference is that the manufacturer's focus is to fulfil customer requirement. Schrage (1999) stated that affordability 'is associated with the benefit-cost ratio' used in economic analysis when resources are constrained and relates the desired benefits to the capital investment required to produce those benefits. 
Manufacturer affordability focuses on the manufacturer's ability to employ its resources (skills, tools and resources) to develop integrated PSS solution to deliver best-value for the customer. The goal of every business is to make profit; hence from the manufacturer's point of view, affordability is concerned with the ability to generate continuous revenue with guaranteed profitability over the life cycle of a project. The authors of this paper have defined manufacturer profitability as the ability of a manufacturer to generate a substantial level of revenue in the delivery of PSS which offsets the cost incurred over the whole life cycle in a contract. Profitability, which is closely associated with growth, is important for a company to gain competitive advantage (Cho and Pucik 2005). However, the nature of PSS solutions often requires the expertise of more than one company to deliver the integrated offering. Often the manufacturer has to engage its suppliers to provide different elements within the PSS offering. This is the reason why affordability is also considered from the supplier perspective.

\subsection{Supplier Sustainability}

Supplier sustainability refers to the supplier's ability to effectively utilise its resources (skills, tools and resources) to provide products and services (functionality) designed to offer the bestvalue (solutions) to the customer. It has the responsibility of ensuring the product or system and/or services remain available as needed and operated at the level of performance and quality required to meet the customer's need. The supplier ensures that highly synthesised products can fulfil customer requirements in terms of performance, cost and effectiveness (Ray et al 2006). In the case of availability contracts, the challenge is to ensure that the supplier's capability can be sustained throughout the life cycle of the project in order to support the manufacturer in the 
delivery of customer requirement. The authors have defined supplier sustainability as the capability of a supplier to maintain products and services in a dependable manner in order to

\author{
Insert Figure (3) here
}

guarantee availability and operability over the project life cycle with flexibility to adapt to changing customer requirement in a cost effective and ethical way. In this paper the manufacturer is the service provider (prime contractor) for a PSS e.g. Rolls Royce, while the supplier refers to the lower tier suppliers who provide various elements of the PSS for Rolls Royce to deliver full capability to the customer.

The three perspectives of affordability are represented in the affordability framework as illustrated in Figure (3). In order to provide an affordable PSS, the customer must be able to afford to procure it given the budget constraint. Equally important is the ability of service provider to recover the investment through the best profit margin (Schrage and Mavris 1994). Thirdly, there is a need for a supply chain that has the capability to deliver and sustain the PSS over the life cycle. This means the customer must be able to afford the PSS; the manufacturer must be able to profit from the offering within the allowable rate defined by the Government "Yellow Book" (non competitive bid) and the lower-tier suppliers must be able to sustain the offering. The three perspectives which are vital to the effective delivery of a PSS are further explored within this paper.

\title{
4. AFFORDABILITY RESEARCH
}

\subsection{Customer affordability}


Customer affordability is a term sometimes used to signify that something is inexpensive or reasonably priced. The definition of customer affordability is often associated with the acquisition or purchase of a product, service or a PSS at a low price which the buyer is willing to pay. Bankole et al., (2009) examined the definition of customer affordability across different sectors which revealed that it is generally explained as the provision of products and services that are affordable to the customer given their budget allocation. The following definitions were identified from the aerospace and defence industries.

Customer affordability is 'the ability to procure a system as the need arises, within a budget, operate at a required performance level; maintain and support it within an allocated life-cycle budget (Kroshl and Pandolfini 2000); 'degree to which the Whole Life Cycle Costing (WLCC) of an individual project or program is in consonance with the long range investment capability and evolving customer requirement' (Ray et al 2006); 'the degree to which the life cycle cost of an acquisition programme is in consonance with the long-range investment and force structure plans of national defence administrations' (North Atlantic Treaty Organisation (NATO) 2007).

The definitions above reveal that the subject is emerging within these industries. Kroshl and Pandolfini (2000)'s definition includes maintenance and operation of the system or product over the expected period of life which is done by the manufacturer in availability contracts. These authors believe that customer affordability definition should address multiple cost considerations for example, total operating costs from cradle to grave. Ray et al. (2006)'s definition of customer affordability is in agreement with that of the US DoD from NATO. Chytka et al (2006) explained that life cycle cost analysis is a systematic approach of applying economics in deciding the best solution for a design over the useful life of the system while affordability analysis employs the outputs of a life cycle cost analysis to apply investment strategies over the life cycle of a system like reserve strategies, etc. This shows the relationship between life cycle costing and customer 
affordability. WLCC includes various costs such as design cost, manufacturing costs, obsolescence costs, maintenance costs, service costs and provision for uncertainty in long-term projects (Romero Rojo et al., 2009, Erkoyuncu et al., 2009). Overall, these definitions have two elements namely: the cost of investment and the customer's income or budget. The standard definition adopted in this paper is Ray et al. 2006's definition which was developed by the NoE in $\mathrm{AE}$ at Cranfield University.

\subsubsection{Authors' Viewpoints of customer affordability}

Some authors wrote from a design perspective while others wrote purely from a financial or operational perspective. Some papers provided definitions of affordability while others did not. Some papers presented the factors that were affecting affordability while others mainly provided measurement techniques for affordability. All these attributes were considered in classifying the papers under five headings based on the research approach namely: design, financial, operational, commercial and conceptual as shown in Table (1). These are also presented as a distribution in Figure (4) which shows that the most of the papers in were in the design category, then the financial category while the conceptual and commercial categories has the same number of papers in those categories.

Design - Papers classified in this category are written from the perspectives of designers considering affordability at the concept and design stages of product or system development. Authors stated that an integrated product and process development approach and open-system architecture are required to design affordable products/systems. The authors evaluated the effectiveness of new technologies such as robust design simulation (an experimental approach to 
design) as part of the roadmap to achieve affordability and stated that affordability can be achieved through the use of technology. Also authors within this category used some examples to show that products can be made more affordable through the reduction of assembly cost as well as the cost of integrating and bonding different parts.

\section{Insert Figure (4) here and Table (1) here}

Financial - These papers are written from the perspectives of the financial impact of customer affordability. Authors provided definitions of affordability and they identified factors affecting affordability within the industries mentioned earlier. Measurement techniques for affordability prediction were also proposed and validated using case studies. An affordability engineering framework and recommendations on how to improve affordability were also provided by authors within this category. Some of the concepts were fully validated while others were yet to be validated.

Operational - Papers in this category are written from an operational perspective. Authors highlight the cost issues associated with the delivery of system of systems solutions. Also of importance is to ensure that different operational scenarios are taken into account in the development and delivery of systems and system of systems solutions. Guidelines for high-level analysis of system of systems costs are provided to aid decision-making in the purchase of systems which must be integrated to enable affordability through interoperability.

Commercial - Papers under this classification are written by companies in the area of program affordability management. Authors highlight the customer affordability challenge of managing various defence programs across the life cycle and propose metrics, tools and approaches to reduce cost at different stages of the life cycle and control long-term projects to ensure that they 
remain affordable. The metrics and tools are not available in public domain, rather they are owned by commercials firm who only deliver based on customer requirement.

Conceptual - Authors within this category proposed different concepts such as customer affordability factors and measurement metrics, without employing any case study, and they suggest measures to improve customer affordability. The contents of the articles grouped under Insert Figure (5) here the conceptual and financial classifications are similar, but the difference is that the articles grouped under financial category contain case studies to validate the techniques developed. Additionally, some of the papers also contained cross case study comparison. Figure (5) shows the key focus of the articles reviewed under each classification. Some of these articles may not available in public domain. This is due to the novelty of the affordability research within the aerospace and defence sectors which means that some of the research might not have been published prior to this time. Also a few articles containing sensitive information may be restricted from public access.

\subsubsection{Customer affordability Assessment}

Two major quantitative factors have been identified which are Customer budget and WLCC of the product or service. Nogal (2006) identified other qualitative factors affecting customer affordability within the aerospace industry which were revised by Bankole, et al., (2009) based on findings from the defence industry to provide the following factors: World economic climate, Political situation, Requirement, Legislation, Global Competition, Supply chain, Performance Related measure, Risk, Value For Money (VFM), Environment and Quality. Each of these factors is explained in Table (2). Kroshl and Pandolfini (2000) used financial metrics as the measure of 
effectiveness for affordability such as Net Present Value (NPV). These metrics employed in measuring customer affordability are represented thus:

$$
\mathrm{NPV}=\sum_{t=0}^{n} \mathbf{F}_{\mathrm{t}}(\mathbf{1}+i)^{-t}
$$

Where $\mathrm{t}=$ time period in years, $\mathrm{n}=$ number of years, $\mathrm{F}_{\mathrm{t}}=$ net cash flow in year $\mathrm{t}$, and $\mathrm{i}=$ interest rate per period.

Current research by the authors of this paper shows the customer (MoD) does not receive revenue from the delivery of the equipment and services (PSS) within availability contracts, rather the PSS Insert Table (2) here

is provided for the end-users who could be the Army, Airforce or Navy. This is the reason why the customer does not assess affordability using the NPV approach. This approach is being employed by the manufacturer to assess the revenue received from the delivery of a PSS. The Systems Analysis and Concepts Directorate at National Aeronautics and Space Administration (NASA) Langley Research Centre developed spreadsheet-based affordability models which take account of variations in time phasing of money, inflation rates, learning curves and batch buy strategies. The model provides a representation of cost against budget and its output is called the 'Sand chart' (Chytka et al., 2006). Also Nogal (2006) developed an Affordability Index (AI) for the aerospace industry including both qualitative and quantitative affordability factors mentioned earlier. Bankole et al., (2009) refined the AI based on their findings within the defence industry to only include quantitative factors to measure affordability for the defence industry as well as conditions in other to obtain a suitable score. This was done in order to ensure accuracy as the nature of qualitative factors differ from quantitative factors and a combination of both factors into one equation would not give an accurate score. The next stage of the research would be focused on using the qualitative factors in assessing customer affordability by generating measures and 
weights for customer affordability which is not covered within this paper. The major (quantitative) factors are presented below.

- CATS - Customer available to spend based on customer budget. This is the financial ability of the customer to procure a PSS.

- WLCC - Whole life cycle cost of a PSS from concept stage to disposal.

These quantitative factors are employed in the new AI which is presented in Equation (2).

$$
\mathrm{AI}=\frac{C A T S}{W L C C}\left(1-\left(\sum_{i=1}^{n} \frac{\left(C_{i}-S_{i}\right)}{S_{i}}\right) \frac{1}{n}\right)
$$

Where: CATS $=$ Total Customer Budget or what the Customer has Available to Spend, WLCC $=$ Whole life cycle cost, $\mathrm{i}=$ the years where cost exceeds the expected spending ability of the customer, $\mathrm{Si}=$ Expected spending ability of the customer for the ith year, $\mathrm{Ci}=$ Cost incurred in the ith year, $\mathrm{n}=$ total number of years the WLCC has exceeded the Total Customer Budget

The conditions to apply this Index are:

(i) if Total Customer Budget (CATS) $>0$

(ii) If Sum of WLCC $<$ CATS or WLCC $=$ CATS, then only apply CATS/WLCC.

(iii) If Sum of WLCC > CATS, then apply full AI. This means there is a violation in the profile.

The result of the AI gives an indication of how affordable a project is in terms of quantitative factors only. An AI that equals to 1 is just affordable, a score greater than 1 is more affordable while a score less than 1 is less affordable.Since the main part of the AI is CATS/WLCC an AI that is equal to one is just affordable as there is just enough CATS to cover the WLCC. AI less than 1 is less affordable because there is insufficient CATS to cover WLCC while AI greater than 1 is more affordable because there is more than sufficient CATS to cover WLCC. Also qualitative factors would impact customer affordability at varying degrees, hence they could be weighted and scored based on their impact. Literature reviewed revealed the lack of research effort in quantifying qualitative factors affecting customer affordability. Another factor which influences 
customer affordability is customer value. This is important factor because the customer must perceive the value in a proposed solution particularly when reviewing tender responses from solution providers. This is usually assessed in terms of VFM within the defence industry.

\subsection{Manufacturer Profitability}

As explained earlier, manufacturer profitability refers to manufacturer's ability to generate sufficient revenue in the delivery of PSS which offsets the cost incurred over the whole life cycle in a contract. Profitability is crucial to the survival of businesses; hence this is important for manufacturers in order to provide and maintain the PSS offering over its lifecycle.

\subsubsection{Manufacturer Profitability Assessment}

Accounting literature reveals that sufficient research has been done in the area of profit assessment and measurement. While profit is generally expressed (Wood 1996) as:

$$
\text { Profit }=\text { Total revenue }- \text { total expenses }
$$

Profitability encompasses more than just profit. Oke (2004) provided the traditional definition of profitability as:

$$
\text { Profitability }=\frac{\text { Revenue }}{\text { Cost }}
$$

The author argued that maintenance of products and systems yields returns to support overall profitability of the manufacturer, hence the maintenance function should be treated as a revenue activity, not just an activity which generates cost.

The definition above is similar to the new AI explained in (section 4.1.1) which is:

$$
\text { AI }=\frac{\text { CATS }}{\text { WLCC }} \text { EMBED Equation. } 3 \text { 圆圆团 }
$$


CATS refers to the total customer budget, while revenue is the income the manufacturer receives from the customer. This shows a similarity between the traditional measure of profitability and affordability. Customer affordability is the customer's focus, while the manufacturer is concerned about profitability. This means the manufacturer's affordability is about its profitability. Anderson and Mittal (2000) investigated the satisfaction-profit chain and stated that it contains links that are asymmetric and nonlinear which add value to the process. Smith (2006) stated that the gross profit margin is crucial in determining how a company can leverage its profit. In order to achieve this, two strategies namely, volume-based strategy (high-margin business) and price/bundling (low-margin business) strategy were applied to different markets. The result showed that the bundling strategy was successful as it was implemented using three different approaches such as platform bundling, customised bundling and convenience bundling which helped to improve a firm's profitability.

Van Raaij (2005) described a valuable model to improve profitability called customer profitability analysis. The analysis starts with the process of discovering the active customers within a specified period of time, analyses the firm's operations to identify the cost drivers of the firm's activities, then it apportions costs (categorised into types) to each customers. This helps to determine which customers are most profitable and how to maximize profitability across all customers. The advantages of the model include the following:

- It provides unique 'insight into costs, revenues, risk and strategic positioning'.

- It yields information about the vulnerability of future cash flows from customers.

- Estimations of future revenues and future costs could be added to the customer profitability analysis to help decision making about the future. 
Within the aerospace and defence industries, manufacturers view suppliers with whom they have long-term relationships as being less risky than those they have only dealt with in the short-term. Other measures of profitability in terms of solvency and efficiency ratios include (Wood 1996):

$$
\text { Gross Profit Margin }=\frac{\text { Gross Profit }}{\text { Sales Revenue }}=100
$$

(Profit before indirect costs have been taken out as a percentage of sales)

$$
\text { Net Profit Margin }=\frac{\text { Net Profit }}{\text { Sales Revenue }} \cdot 100
$$

(Profit after all costs have been taken out as a percentage of sales)

$$
\text { Return On Capital Employed }(\text { ROCE })=\frac{\text { Earnings Before Interest \&Tax }}{\text { Total Assets - Current Liabilities }}
$$

(Indication of the efficiency and profitability of a company's capital investments)

$$
\text { Return On Investment }: \text { ROI })=\frac{\text { Operating Income }}{\text { Investement }}
$$

(Indication of the efficiency and profitability of a company's capital investments)

$$
\text { Return On Owner's Equity }(\text { ROOE })=\frac{\text { Net Income }}{\text { Owner's Equity }}
$$

(Profit after taxes in relation to owner's equity)

\subsection{Supplier Sustainability}

The authors of this paper have described supplier sustainability as the capacity of a supplier to maintain products and services and ensure that they are available and in full operation over the whole life cycle of a PSS. This requires the supplier to remain sustainable and financially viable over the project life. The delivery of a complete PSS capability is not only down to the manufacturers, but also their supply network. The effective management of the supply chain can enable a service provider to gain competitive advantage and improve its profitability by enabling 
it succeed on the dimensions of cost, quality, response time and flexibility (Presutti Jr. and Mawhinney, 2007). A review of literature revealed existing measures for assessing the performance of suppliers. Gunasekaran, et al., $(2001,2004)$ identified three levels of hierarchy in the measurement of supplier performance namely; strategic (top-level), tactical (middle-level) and operational (low-level). The outcome of the review resulted in the development of a framework to measure the performance of the suppliers based on literature review and the results of an empirical study of selected British companies. The metrics identified were grouped under four categories reflecting four supply chain activities or processes namely; plan, source, make/assemble and delivery. Similar measures were employed by the Supply-Chain Council in assessing the performance of the supply chain to develop the Supply-Chain Operations Referencemodel (SCC 2009, Ball and Bititci, 2006). Lee (2004) stated three important characteristics for sustainable competitive advantage such as agility, adaptability and alignment. However, while existing metrics are effective in measuring the performance of suppliers, they do not specifically assess the suppliers' ability to continue to exist and grow over the lifecycle of the PSS solution. A review of literature on sustainability revealed that many authors focus on environmental sustainability under three dimensions of sustainability namely social, economic and environmental (Labuschagne et al., 2003). These measures do not include the financial (cost) dimension as a major focus, but authors of this paper believe financial dimension which impact long term viability should also be included. Supplier sustainability of PSS is closely linked with business sustainability (Elkington, 1997) as it focuses on the capability of the supplier to remain sustainable over the duration of the contract. One way to achieve this overall capability and successfully deliver customer requirement in the PSS is technological sustainment (Sandborn and Myers, 2008). A framework for sustainability developed by Griffith University (2009), Australia, 
contained five dimensions of managing sustainability namely, people, resources, financial, community and environment. The authors of this paper have refined these dimensions based on existing supplier sustainability measures and proposed five dimensions for supplier sustainability.

\subsubsection{Supplier Sustainability Assessment}

The supplier assessment and measurement metrics which are related to sustainability are shown in Figure (6). These measures were selected from existing measures of supplier performance because they give an indication about the long term sustainability of suppliers. The authors have refined Griffith University's dimensions of managing sustainability and grouped the performance measures under the five dimensions. The measures would enable the manufacturer deliver the desired outcome of the contract such as availability or capability to the customer. Availability could be a performance measure as well as an outcome of the whole project. As a performance

$$
\text { Insert Figure (6) here }
$$

measure, availability is linked to the 'management of people and resource' dimension in Figure (6) under the project management and ability to manage customer asset measures.

In order to adequately measure the supplier sustainability, a manufacturer would need to measure the performance of its suppliers over a period of time and compare results from one period to the other e.g. monthly or yearly in order to identify trends. This would provide an indication of the sustainability of the supplier over the life cycle of the contract.

\section{INDUSTRIAL PRACTICE}

The main findings are presented in sections 5 and 6 from the three perspectives of affordability. 


\subsection{Customer Affordability}

Typically within the UK defence sector, there is one main customer and many contractors. First, a need is identified, and then a budget is allocated internally by the customer. Due to the overall defence budget constraint, employees could underestimate the cost of the contract in order to gain approval at the top level, leading to the allocation of a lower budget than actual cost required throughout the life cycle of the contract. This might cause a project to become unaffordable later on in the project life cycle, but this practise may not apply to every contract. After budget allocation, contractors are invited to tender for the contract at the bidding stage, and then contract is negotiated within certain parameters before it is finally awarded to a prime contractor with the consideration of WLCC and risk. Customer affordability of a contract is measured by comparing the customer budget with the WLCC of a defence project without using an AI or measurement metrics. Different types of defence contracts exist, but currently there is a shift from spares and repairs contracts to availability contracts. The nature of availability contracts is one in which the customer outsources services which would have been provided in-house to prime contractors to only pay for the period of time when the equipment is available to satisfy defence need, similar to the U.S. Performance Based Logistics initiatives (MoD, 2005). A typical availability contract lasts typically between 5 and 40 years with a five yearly review. Capability contracts are concerned with the provision of a capability rather than platform availability and these could last longer than availability contracts. The defence sector aims to move from availability to capability contracts, hence is it important that the customer has the financial ability to support the contracts not just at the time of contracting, but throughout the life of the contract. One of the major reasons that could cause defence projects to become unaffordable is wrong estimates or underestimation of through 
life costs. Others include design flaws, increasing lifecycle costs and failure to meet performance targets. This highlights the importance of getting the through life estimate right and the customer being able to assess its budget allocation to procure and support the contract. Usually, the customer does not disclose exact information about its budget allocation; rather it provides contractors with a range of customer budget. This is done in order to achieve cost savings and obtain the lowest possible price, especially in competitive bids. However, it has also emerged that uncertainty is not only inherent within cost estimates, but also in the customer budget. This is due to financial constraints facing the defence budget at the top level which eventually affects individual projects. This could occur as a result of changes in government priority meaning that a higher proportion of the national budget is allocated to other industries like health, education etc. and less allocation to defence.

\subsection{Manufacturer Profitability}

Within the aerospace and defence industries, the UK Government Review Board conditions will affect manufacturer profitability by determining the rate of profit that manufacturers can use when contracting. For example, the Basic Profit rate in 2009 was $9.74 \%$ for non-competitive government contracts. This could vary in other contracts (MoD; 2009). However, within the UK defence industry, the manufacturer could only improve profitability by ensuring that its actual costs are less than estimated cost in order to improve its profit margin. Profitability assessment at the bidding stage when contracting for defence projects is focussed on generating a competitive offer or selling price. In non-competitive government contracts, the UK MoD stipulates the baseline profit rate for the manufacturer after giving allowance for the fixed capital servicing and working capital servicing (MoD, 2009). Different approaches are employed by manufacturers in 
assessing profitability depending on the nature of the project. Typically, the techniques include the elements such as basic costs (labour, overheads, materials and supply chain), contingency, escalation, profit rate and add-on costs. Typical example of profitability assessment is presented in Table (3) within the defence and aerospace industries.

- Total Basic Cost - this comprises of the variable and fixed costs which are fundamental for the delivery of customer requirement. These include labour, overheads, raw materials and supply chain. Supply chain figure is an estimate of sub-contractors and other costs associated from suppliers.

- Contingency estimate includes the cost of risk and uncertainty.

Insert Table (3) here

- Escalation is similar to contingency, but it addresses increase in cost due to price increase or exchange rate fluctuations.

- Basic Selling Price is generated after basic profit has been added on to the sub-total of costs.

- Total Add on-Costs are generated as a result of other costs which would vary from one contract to another such as warranty or penalty. The costs are affected by the nature of the contract, e.g. imports from other countries, penalties imposed by the customer or duties to be paid to the government.

- Minimum Selling Price is generated after total on-costs and profit have been added to basic selling price.

- Offer Price contains the addition of basic selling price and total add on-cost. The offer price is the starting point for negotiation with the customer. A negotiation margin could be added to this price. 
Factors which could affect the profitability of defence manufacturers include Cost, Uncertainty and risk, Competition, Project life cycle and Economic climate.

- Cost - this refers to the total cost associated with a PSS from the concept stage to the disposal. It also includes the cost of obsolescence, maintenance and service costs. An increase or decrease in WLCC cost could have a significant impact on the profit margin.

- Uncertainty and Risk - As explained in Table (2), it the combination of the probability of any event occurring and its consequences (positive or negative) on the PSS offering. Uncertainty in WLCC or CATS could have a negative or positive effect on profitability as actual cost or budget could be lower or higher than the budget. Usually manufacturers build in contingencies to cover themselves against potential risks.

- Competition - this could affect profitability particularly in a competitive bid. If other contractors are offering lower prices (lower profit margin), a manufacturer could be forced to provide a lower selling price leading to lower profit margin in order to win a bid.

- Project life cycle - the duration of availability contracts within the defence industry which could last between 5 and 40 years guarantees continuous revenue for the manufacturer over a longer duration more than contracts of shorter duration.

- Economic climate - the economic climate can affect profitability as cost escalation could occur due to rising interest rate, inflation, labour rate and exchange rate. This would reduce the profit margin as higher costs are incurred.

\subsection{Supplier Sustainability}

Within the defence and aerospace industries, manufacturers measure the performance of the suppliers using different techniques. An industry-wide initiative, $21^{\text {st }}$ Century Supply Chains 
(SC21) 'is a change programme designed to accelerate the competitiveness of the aerospace and defence industries by raising the performance of its supply chains' (SC21, 2009). The implementation of the initiative focuses on three streams.

- Certification and quality improvement - common standards such as AS/EN 91XX and Nadcap are adopted across industry as the quality standards. AS/EN 91XX is the standard for quality management systems while Nadcap is a standard for assessing the manufacturing processes such as chemical processing, coatings, composites, surface enhancement etc.

- Development and performance - This process has four elements: sustainable improvement, performance metrics, improvement framework and recognition. For sustainable improvement, an Act-Plan-Do-Review Model is employed which is linked to key performance indicators. Performance metrics based on delivery and quality are also developed to measure the performance of suppliers within the supply chain. Two of these measures are represented below.

Delivery $=($ Number of OnTime deliveries $) /($ Number of schiuled deliveries $)($

Quality $=1-($ Number of rejects $) /($ Number of deliveries $) * 100(0(11)$

Number of 'On Time' deliveries refers to number of products e.g. steel delivered on-time at the agreed date Number of Scheduled deliveries refers to number of products planned for delivery at an agreed date Number of rejects refers to number of products rejected after delivery

Number of deliveries refers to number of products delivered at an agreed date

In addition to this, the European Foundation for Quality Management excellence framework is adapted to measure performance and achieve excellence together with Lean manufacturing principles. Recognition is done through an award system which gives gold, silver or bronze awards based on the three elements explained above. 
- Relationships - The programme adopts a view that the manner of interaction and communication between suppliers would impact the industry's performance. In order to assess supplier relationship, a code of practice was developed. This comprises five elements, namely: communications, through life capability management, continuous improvements, commercial agreements and ethics (SC21, 2009).

Companies within these industries adopt different measures in assessing their supplier performance, but the idea of assessing operational and financial sustainability is not common. The assessment of operational financial sustainability is also in its infancy within academia. While most of the metrics presented in Section 4, Figure (6) as well as those employed by the SC21 are focused on the measurement of products and processes (SC21 2009), little or no measures have been developed for the measurement of services.

\section{Customer Affordability Management}

\subsection{Un-affordability}

Un-affordability here refers to a situation where the customer cannot afford to procure or sustain a product, a service or a PSS. It could occur where the customer's affordability position is getting worse as the WLCC is exceeding the customer's budget. Generally, un-affordability can be caused by a number of factors across the phases of the CADMID cycle as shown in Figure (7). 
- Performance requirement - If a project cannot be delivered to meet user requirement because equipment is under performing or the customer overstated the functionality that would be obtained from new technology, it would be considered unaffordable. As soon as this is discovered at the earlier stages of the project life cycle, steps are taken to help correct the failure which could have a cost impact.

- Design flaws - if there are technical flaws in the design of a system or equipment and the manufacturer is not able to correct them, the contract could be brought to an end as the final equipment would not meet customer requirement. This could be discovered at the early stages of the project life cycle.

- Time - it is very important that the manufacturer can deliver the project within the required time frame as the longer a project takes, the higher the cost of project delivery. This could lead to a project becoming unaffordable. This may not be discovered until later stages of the project life cycle.

\section{Insert Figure (7) here}

- Additional cost - this could occur due to number of reasons especially at the Demonstration phase of the CADMID cycle. If the system involved within the project is common, its components could be produced at a lower cost, while a be-spoke system could lead to significant cost increase e.g. the NIMROD aircrafts. This may not be realised until later stages of the project life cycle.

These factors could cause a project to become unaffordable during the life cycle, however, they can be managed in order to improve the affordability position of the project. This is discussed below. 


\subsection{Programme Affordability Management}

In order to avoid defence projects becoming unaffordable, it is important to have a method of managing and controlling the project to ensure that it is being implemented within the resources available. An effective process of management would detect when the actual deviates from the target, appropriate measures would be taken which could include providing additional resources required to deliver the contract on time and within schedule and resources. Within academia and industrial practice, techniques such as earned value management, value management methodology and some parametric costing techniques are utilised to assess the performance of a defence project by measuring the value created through the use of resources. Other techniques are commercially developed by vendors such as PRICE Systems, to manage complex programs.

\subsection{Key observations from industrial interactions}

A summary of the findings from industrial interaction are provided below.

- The defence environment is moving from spares and repairs contracts towards service and performance-based contracts like availability and capability contracts

- The main defence customer has budget constraints which could affect customer affordability of defence contracts alongside the WLCC.

- The customer affordability could be affected by the project team underestimating the cost of the project in order to gain approval at the top-level to secure the contract.

- Projects can become unaffordable due to underestimation of costs, design flaws and inability to meet performance targets at different stages of the life cycle.

- Uncertainty is inherent within cost estimates and also the customer budget. 
- The customer does not always disclose the amount of budget available to the manufacturer in a competitive bid in order to achieve cost savings.

- Upon contract award, the manufacturer engages closely with the customer to agree on the terms of the contract.

- The manufacturer is the solution provider who takes responsibility for the delivery of the contract; hence it is incentivised by continuous revenue from the customer.

- The manufacturer may select its own sub-contractors to be involved in delivering the contract or the customer may stipulate that certain subcontractors are engaged within the project.

- Supplier selection is done based on the manufacturer's internal assessment procedure by the supplier engagement team

- SC21 is the defence industry's initiative to encourage competitiveness among defence suppliers by raising the performance of its supply chains

- The sustainability of defence suppliers is very important to ensure that the manufacturer can deliver the defence contract.

This shows that the move from spares and repairs contracts is not without its own challenges especially due to uncertainty. The PSS business model needs to be fully understood and adequate provision must be made to procure and sustain delivery of defence projects. The major players which are customer, manufacture and supplier need to work closely to obtain mutual benefits. The gap between industrial practise and academia is explored in section 7.

\section{GAP ANALYSIS AND CONCLUSION}

\subsection{Industrial practice and Academia}


From the review of literature and industrial interaction, a comparison was made between industrial practice and academic research. These reflect the need for further research in the area of affordability particularly in the formulation of metrics for assessment and control of affordability in industry and academia.

The findings presented in Table (4), reveal that a customer affordability definition has been developed and accepted within academia while this is not the case in industry. A measurement metric has been developed within academia which is does not exist in industry. This suggests that academic effort to develop customer affordability is higher than that of industry. Industry could adopt the output of the academic findings. Profitability is generally not defined and it has an established method of measurement both within industry and academia, however the focus differs. Industrial profitability assessment includes assessing profitability to determine the best price prior to contracting, but academia usually views affordability as an activity at the end of the trading period year. There is no working definition for supplier sustainability in both industry and academia, but academic research is a step ahead. Supplier performance measures exist in academia and industry, but measures for supplier sustainability are just being developed in academia. This could be embraced and further developed by industry.

\section{Insert Table (4) here}

\subsection{Conclusion}

This paper set out to examine the current state of research in affordability within the defence and aerospace industries alongside industrial practice. Due to the novelty of the research focus, the research methodology employed included materials and articles from academic and non-academic 
sources such as academic writings, industry reports, and unpublished working papers between the period of 1983 and 2008. In addition, current practice in the area of affordability was captured. In conclusion, the observations made from this study are expressed below.

Two major (quantitative) factors affecting customer affordability are CATS and WLCC. Additionally, there are other qualitative factors affecting customer affordability which are: Requirement, Quality, Supply chain, Value For Money, Environment, Risk, World Economic Climate, Risk, Legislation, Political Climate, Performance-Related measure, Global Competition and Unknown. Some of the qualitative factors can be influenced by the manufacturers while others may not be influenced by them. It is important that the manufacturers are able to determine and focus on the factors which are within their control in order to be able to improve customer affordability. This could be useful in developing guidelines for assessing customer affordability based on the qualitative factors. Also, these factors affect customer affordability at varying degrees within different contracts hence it would be useful to develop a system of capturing and representing the importance of these factors.

A similarity was identified between the main part of the AI and the traditional measure of profitability. This supports the idea that manufacturer affordability is based on its profitability. In terms of manufacturer profitability, the customer states the rate of profitability the manufacturer is allowed to have. This has a way of constraining the level of profitability that could be achieved by the manufacturer within UK defence. However, the manufacturer could improve it overall profitability across the organisation by employing some of the strategies identified within this review such as volume-based strategy (high-margin business) and price/bundling. Profitability is not only affected by the stipulated profit rate and revenue from the customer. It is also affected by risk. Risk is described at the probability of occurrence and its consequences on the PSS offering. 
The impact or consequence of risk would affect profitability because if risk is not properly assessed within the PSS solution, the impact of risk might be much higher than expected which would increase the cost of the PSS solution and reduce manufacturer profitability. Several risk assessment methods exist; hence the manufacturer should employ the most suitable approach to make adequate provision for risk.

In terms of supplier sustainability, the measures presented within this paper are generic and some of them may be less suitable for availability contracts. There is a need to validate the measures and narrow down to the measures which are most suitable for this type of contracts. Also most of the measures are focused on measuring the supplier sustainability in terms of products and processes. There is a need to identify measures for supplier sustainability based on service provision since PSS offering like availability contracts integrates products and services. There is little academic literature defence available on established methods of project monitoring and control according to this review, hence future work could be done to investigate this theme. Also future work could be done to develop frameworks for affordability based of the findings from the three perspectives. A study of affordability across different industries could also be useful in further research. The limitation of the study is the constraint of accessibility of published materials in the area of work which is the reasons why industrial practice is included in the review. Overall this review paper provides an accurate view of affordability within the defence and aerospace industries. 


\section{REFERENCES}

Al-Churaiz Yusuf and Enshassi Adnan (2005), “Ability and willingness to pay for water supply service in the GAZA strip," Building and Environment, 40, 1093-1102.

Anderson, W. E. and Mittal V., 2000. Strengthening the Satisfaction-Profit Chain. Journal of Service Research, 3, 107- 120.

Acquisition Operating Framework 2008. Technology Readiness Levels (TRLs). Ministry of Defence [Online]. Available from: http://www.aof.mod.uk/aofcontent/tactical/techman/content/trl_applying.htm. [ Accessed 19 July 2010].

Aurich J.C., et al, 2006. Life cycle oriented design of technical Product-Service Systems. Journal of Cleaner Production, 14 (17), 1480-1494.

Baines, S. Tim et al., 2007. The state-of-the art in Product Service System. Proceedings of the Institution of Mechanical Engineers, Part B: Journal of Engineering Manufacture, 221(10), 15431552

Bankole, O. O. et al., 2009. Current Practice in Affordability Assessment of Product-Service Systems within the Aerospace and Defence industries. Proceedings of the $1^{\text {st }}$ CIRP IPSS Conference, 1-2 April, 2009 Cranfield University, Cranfield, UK, 230-237.

Bankole, O. O. et al., 2010. A prediction system for assessing customer affordability of whole life cycle cost in defence Industry, Journal of Intelligent Manufacturing, .

Ball, P.D. and Bititci, U.S., 2006. Supply Chain management diagnostics and improvement approach. Control (Institute of Operations Management), 32(4), 20-24. 
Bever Bob and Collofello S. James (2002), “An investigation of techniques for addressing software affordability," IEEE Aerospace Conference Proceedings, 5-2577-5-2585.

Bradbery Ronald (2005), “Development of a descriptive framework for affordability engineering”. MSc Thesis, Cranfield University, School of Industrial and Manufacturing Science, Cranfield, UK.

Centre for Transit-Oriented Development and Centre for Neighbourhood Technology (2006), "The Affordability Index: A New Tool for Measuring the True Affordability of a Housing Choice”, The Urban Markets Initiative, Market Innovation Brief.

Cho H. and Pucik V., 2005. Relationship between innovativeness, quality, growth, profitability and market Value. Strategic Management Journal, 26(6), 555-575.

Chytka, T. M. et al., 2006. An Integrated Approach to Life Cycle Analysis. NASA Langley

Research Centre American Institute of Aeronautics and Astronautics, Inc., 3, 1-15.

DeMarco, A. Anthony, 2005. Making the Case for program Affordability management. Price Systems Report [online]. Available from:

http://www.pricesystems.com/solutions/AffordabilityManagement.asp [Accessed 4 November 2009].

Daugherty G., 1989. Contracting for Supportability and Affordability. Reliability and Maintainability Symposium, 1989. Proceedings., Annual, Atlanta, GA, USA, 24-26 Jan 1989, 321 $-327$.

Elkington, J., 1997. Cannibals with Forks: The Triple Bottom Line of 21st Century Business, Capstone Publishing Ltd., Oxford. 
Erkoyuncu, J. A. et al., 2009. Uncertainty challenges in service cost estimation for productservice systems in the aerospace and defence industries, Proceedings of the $1^{\text {st }}$ CIRP IPSS Conference, Cranfield University, Cranfield, 200-206.

Fankhauser Samuel and Tepic Sladjan 2007. Can poor consumer pay for energy and water? An affordability analysis for transition countries, Energy Policy, http://www.informaworld.com/smpp/title $\sim$ content $=\mathrm{t} 713426247 \sim \mathrm{db}=\mathrm{all} \sim \mathrm{tab}=\mathrm{issueslist} \sim \mathrm{branches}=$ $\underline{20-v 2035,1038-49}$

Finlay, S.M. 2006. Predictive models of expenditure and for assessing the affordability of new consumer credit applications, Journal of the Operational Research Society, 57, 655-696.

Goedkoop, M. et al., 1999. Product Service-Systems, ecological and economic basics. Report for Dutch Ministries of Environment (VROM) and Economic Affairs, The Netherlands.

Griffith University, 2009. What is Sustainability [online]. Office of facilities Management, Australia. Available from: www.griffith.edu.au/.../content_definition.html [Accessed 19 January, 2010]

Guimaraes L., et al., 2003. Energy Affordability in the Sahelian region, Applied Energy, 76, (1-3), $9-13$.

Gunasekaran, A. et al., 2001. Performance measures and metrics in a supply chain environment. International Journal of Operations and Production Management, 21, 71-87.

Gunasekarana, A. et al., 2004. A framework for supply chain performance measurement. International Journal of Production Economics, 87, 333-347.

Hancock, K. E., 1993. Can Pay? Won't Pay? or Economic Principles of Affordability, Urban Studies, 30 (1), 127-145. 
Kong D and De Kock F, 1997. Affordable and reliable Power systems for Telecommunications In Africa, 19th International Telecommunications Energy Conference, 1997. INTELEC 97,

Melbourne, Vic., Australia, 19-23 Oct 1997, 141 - 145.

Kroshl, W.M., and Pandolfini, P.P., 2000. Affordability Analysis for DARPA Programs. Johns Hopkins APL Technical Digest, 21(3), 438 - 447.

Labuschagne, C. et al., 2003. Assessing the Sustainability performances of industries. Journal of Cleaner Production, 13(4), 373-385.

Lee, H., 2004. The Triple-A Supply chain. Harvard Business Review, 102-112.

Marasco A., 2008. Third-party logistics: A literature review. International Journal of Production Economics, 113 (1), 127-147.

Lee A.J. et al., 2006. Affordable, safe housing based on expanded polystyrene (EPS) foam and a cementious coating, Journal of Materials Science, 41(21), 6908-6916(9).

Lerman, D.L and Reeder, W.J. 1987. Affordability of Adequate Housing, AREUEA Journal, 15(4), $389-404$.

Meier, H., Roy, R. and Seliger, G., 2010. Industrial Product-Service Systems - IPS2. CIRP Annals - Manufacturing Technology, 59 (2), 607-627.

Ministry of Defence, 2005. Defence Industrial Strategy: Defense White Paper. The Stationery Office, London Cm 6697.

Ministry of Defence, 2009. Report on the 2009 Annual Review of the Profit Formula for Noncompetitive government contracts [online]. Available from:

http://www.mod.uk/NR/rdonlyres/2C810965-1069-43CF-ACC726B88AF3522D/0/090130_2009ar_final.pdf [Accessed: 19 January, 2010]. 
Minkiewicz A.F., 2006. Tackling the Cost Challenges of Systems of Systems, the Journal of Defense Software Engineering, Cross Talk, 10-14.

Mueller M.L. and Schement J.R., 1996. Universal Service from the Bottom Up: A study of Telephone Penetration in Camden, New Jersey. The Information Society, 12 (3), pp. 273-292. Mutchler J. and Krivo, J. L., 1989. Availability and Affordability: Household Adaptation to a Housing Squeeze, Social Forces, 68, 241-261.

$\mathrm{Ng}$ I., et al., 2009. Outcome-based contracts as a driver for systems thinking and service-dominant logic in service science: evidence from the defence industry, European Management Journal, 27 (6), 377-387.

Ngai E.W. et al., 2008. RFID research: An academic literature review (1995-2005) and future research directions, International Journal of Production Economics, 112 (2), 510-520.

Nogal M., 2006. Development for framework for Affordability Engineering Measurement. Thesis (Msc- unpublished), Decision Engineering Centre, School of Applied Sciences, Cranfield University, Cranfield, UK.

North Atlantic Treaty Organisation, 2007. Methods and Models for Life cycle costing. Final Report of Task Group SAS-054, June 2007, Annex D, D1.

Oke, S.A., 2004. An analytical model for the optimization of maintenance profitability. International Journal of Productivity and Performance Management, 54(2), 113-136.

Jaffe , M. O., 1983. Weigh affordability vs. profitability to price EFT products, services, Bank systems and equipment, 20 71-75.

Presutti Jr D. and Mawhinney, R. J., 2007. The Supply Chain- FINANCE Link. Supply Chain Management Review, 32-38.

Rains D. A, 1996. Naval Ship Affordability, Naval Engineers Journal, 108(4), 19-30. 
Ray A., 2006. A cost model for affordability for aircraft components, Thesis (Msc - unpublished), Queens University Belfast.

Ray A., et al., 2006. Developing a Framework for Affordability Engineering. The $4^{\text {th }}$

International Conference on Manufacturing Research (ICMR 2006), Liverpool John Moores

University, $5^{\text {th }}-7^{\text {th }}$ September 2006, ISBN 0-9553215-0-6, 11-16.

Ray. A. and Roy R., 2007. Affordability Engineering - Scope, Challenges and References, White

Paper, Network of Excellence in Affordability Engineering, School of Applied Sciences,

Cranfield University, UK (unpublished).

Reagan L., 2004. Affordability Management in a Performance-Based World. Price systems, 1-6.

Reagan L., 2005. Affordability Simulation: Cost Analysis in a Simulation Environment. Price systems, $1-4$.

Redman, Q. and Stratton, G., 2001. Why Affordability is a systems engineering metric. Digital Avionics Systems, the 20th Conference, 1, 4B3/1 - 4B3/12

Roark, C. and Kiczuk, B. 1996, "Open Systems: a process for achieving affordability", IEEE Aerospace and Electronics Systems Magazine, vol. 11(9), pp. 15-20.

Romero Rojo, J. F., et al., 2009. Obsolescence Challenges for Product-Service Systems in Aerospace and Defence Industry. Proceedings of the $1^{\text {st }}$ CIRP IPSS Conference, 1-2 April, 2009 Cranfield University, Cranfield, UK, 255-260.

Roy R. et al., 2006. Development of Framework for Affordability Engineering Measurement. Manufacturing Department, School of Applied Sciences, Cranfield University, UK (unpublished). Roy R. and Cheruvu K., 2009. A competitive framework for Industrial Product Service Systems. Accepted for International Journal of Internet Manufacturing and Services, Special Issue on Product Service Solutions in Life-Cycle Activities. 
Rubin, Scott J., “Are Water Rates Becoming Unaffordable?,” Journal American Water Works Association , 79-86.

Russell J.D., 2007. Composites Affordability Initiative: Successes, Failures- Where do we go from here? SAMPE Journal, 43, 26-36.

Sandborn P. and Myers J., 2008. Designing Engineering Systems for Sustainment, Handbook of Performability Engineering, ed. K.B. Misra, Springer, 81-103, London [Online]. Available from: http://www.enme.umd.edu/ESCML/Papers/SustainmentChapter.pdf [Accessed 1 August 2010]. SC21, 2009. $21^{\text {st }}$ century supply chain Awareness presentation [online]. Available from:

http://www.sbac.co.uk/pages/80338686.asp [Accessed 21 October 2009].

Schrage, P.D., 1999. Technology for Rotorcraft Affordability Through Integrated Product/Process Development. American Helicopter Society $55^{\text {th }}$ Annual Forum, Montreal Canada.

Schrage P. D., and Mavris D., 1994. Technology for Affordability - How to define, measure, evaluate and implement it? The American Helicopter Society $50^{\text {th }}$ Annual Forum, May 11-13, 1994, Washington, DC., 1039 -1053.

Schmidt J. and Hitt E., 1999. Air Force Ownership Costs (AFTOC) and Reduction in Total Costs (R-TOC), AIAA/IEEE Digital Avionics Systems Conference, 1999 Proceedings. 18th, St Louis, MO, USA, 24 Oct 1999 - 29 Oct 1999, 1. SS.2-1 - SS.2-6.

Semple, J., 2007. Review into Affordability Housing Final Report, Department for Social Development in Northern Ireland, 1-68.

Smith, E. G., 2006. Leveraging profitability in low-margin markets. Journal of Product \& Brand Management, 15 (6), 358-366

Smyth, P. 2005. Water and Wastewater Finance and Pricing. Taylor and Francis Group LCC., 309-323. 
Soraya M., et al., 2000. Enhancing Affordability of power Electronic Subsystems - A success story. Digital Avionics Systems, 2001. DASC. The 20th Conference, Daytona Beach, FL, USA, 14 Oct $2001-18$ Oct 2001, 1.4D2/1 - 4D2/6

Supply-Chain Council, 2009. Supply-Chain Operation Reference-Model (SCOR Overview, Version 8.0) [online]. Supply-Chain Council, Available from: http://archive.supplychain.org/galleries/default-file/SCOR\%2080\%20Overview\%20Booklet2.pdf [Accessed 21 October 2009].

Tsolacos Sotris, McGough Tony and Thompson Bob (2005), “Affordability and performance in the industrial property market," Journal of Property Investment and Finance, 23 (4), 311-328. Tukker A., 2004. Eight types of product-service system: Eight ways to sustainability? Experiences from Suspronet. Business Strategy and the Environment, 13, 246-260. Van Raaij, M. Erik., 2005. The strategic value of customer profitability analysis. Marketing Intelligence and planning, 23 (4), 372-381.

Wood F., 1996. Business accounting, Volume 1. Pitman.

Young R. and Reagan L., 2004. Program Affordability Management Centre of Excellence. Price systems. 